\title{
THE CONFLICTING IMPLICATIONS OF THE RIGHT TO INFORMATION AS RECOGNISED BY PUBLIC INTERNATIONAL LAW
}

\author{
Bilyana Borisova MANOVA \\ "Neofit Rilski" South-West University, Blagoevgrad, Bulgaria \\ bili.manova@gmail.com
}

\begin{abstract}
The present article outlines the most significant stages in the gradual development of international law towards a recognition of a right to information. It explores the instruments and judicial decisions in which this right has been acknowledged as well as the conditions under which it may be exercised including the categories of requesters entitled to it, the kinds of information that may be accessed and the purposes of such access. The article further examines the manifold and often conflicting aspects of the right to information and its relation to concepts such as democracy, security, freedom of expression, right to private life, corporate secrets, investigating journalism and whistleblowers. In particular, it analyses the importance of the access to information about the exercise of political power by public authorities and the crucial role it should play in enabling wellfunctioning democratic societies where responsible government, public scrutiny over the political processes and a right to an informed participation in public affairs is effectively guaranteed to all citizens. However, the risks that the public access to information poses to national security and to the well-recognized right to private life are also taken into account.
\end{abstract}

Keywords: right to information, participation in public affairs, security, private life, risks

\section{Introduction}

In the course of the last two decades, public international law (PIL) has gradually accepted the existence of a human right to information (RTI). However, the international legal framework of this right still needs to define more clearly its content and the situations in which it may be invoked. While RTI enhances and enables freedom of expression, democracy, transparency, accountability, its relations to other public interests are controversial since a RTI that is too wide in scope might put at great risk national security and the privacy of other citizens. Therefore, it is essential for international instruments and jurisprudence to determine unambiguously the limitations of the RTI.
2. Development of public international law towards an acknowledgement of a right to information

The explicit recognition of a right to government information both by national laws and by PIL is a recent development. In that regard PIL had to catch up with national legislations that were the first to acknowledge the existence of a RTI of their citizens. The first state to ever introduce a law granting 'individuals the right to access information held by public bodies' was Sweden as early as 1766 [1]. However, it was not until the late $20^{\text {th }}$ century that RTI laws began to grow in number - first in Western Europe and the USA, then in Eastern Europe, Asia and more slowly - Africa [2]. In the last 20 years RTI has been acknowledged by 'a growing number of constitutions' [3] a large number of states have adopted special RTI laws [4]. 
Currently over 100 states have introduced such legislation [5]. Nevertheless, Mendel considers that there still is "certainly room for growth' [6] of the national RTI legislations, particularly in the Middle East, and North Africa.

Similarly, PIL also began to admit the existence of a RTI, though initially not as an intrinsic right. Rather, at the beginning the RTI was seen as merely a necessity for the enjoyment of other 'stand-alone' rights [7].

Most often the recognition of a RTI (that is, a right of the recipient) has been justified on the basis that it secures the right to freedom of expression (of the speaker) [8]. Hence, it is no coincidence that international instruments providing for the protection of human rights often refer to the relation existing between the RTI and the right to freedom of expression and deal with the two in the same provision [9]. Examples of such instruments abound: the 1948 Universal Declaration of Human Rights (UDHR) [10], the 1966 International Covenant on economic, civil and political rights (ICCPR) [11], the 1950 European Convention on Human Rights and Fundamental Freedoms (ECHR) [12].

As McDonagh points out, there is room for debate whether the RTI should be recognised as a separate human right ('intrinsic right' approach), or, rather as a precondition for the enjoyment of other rights ('instrumentalist' approach) [13]. New as the recognition of a RTI by PIL may be, the understanding of it as an intrinsic right is even newer. It was first proclaimed in 2004 by the UN Special Rapporteur on Freedom of Expression [14] in relation to the principle of maximum disclosure [15]. The biggest breakthrough so far was the publishing in 2011 of a new General Comment on Article 19 of the ICCPR [16] by which the UN Human Rights Committee (UNHRC) 'expressly acknowledged that Article 19 embraces a general right of access to information' [17].

As for human rights treaties, until 2009 they did not explicitly guarantee a RTI [18]. Yet, some of their provisions granting other rights were interpreted as to contain an implicit RTI needed for the enjoyment of those other rights. Important documents in that regard have been the UDHR [19], the ICCPR [20], the 2009 Council of Europe Convention on Access to Official Documents [21] as well as the 1998 Aarhus Convention [22] (as regards the information related to environmental matters).

Even though the drafters of milestone documents such as the UDHR and the ICCPR may not have initially intended so [23], a wider interpretation of Art. 19 of the UDHR and Art. 19 of the ICCPR emerged according to which a RTI may be derived from them [24]. Thus, the UDHR which guarantees a right 'to hold opinions without interference and to seek, receive and impart information and ideas through any media' [25] has been interpreted to embody a RTI [26]. Similar terms are employed in the ECHR [27] and in a like manner, an RTI has also been derived from certain articles of the ECHR [28].

A further important moment was the adoption in 1998 of the Aarhus Convention [29] which provides for a right to environmental information held by the authorities, including information 'on policies or measures ..., or on the state of human health and safety where this can be affected by the state of the environment' [30] in order to achieve public participation in the decision-making [31]. It embraces a wide definition of 'public authorities'[32] and of the 'public concerned'[33]. In addition, the Convention envisages review procedures of measures that have been introduced by disrespecting the RTI [34].

That being said, by far the most crucial step so far towards the recognition of a RTI has been the adoption of the Convention on Access to Official Documents [35] which is the 'first ever international convention on access to information' [36]. This instrument also adopts a broad definition of public authorities [37], lays down a right of access to official documents [38] held by them and determines the rules and procedures applicable to the processing of requests 
[39]. Applicants do not need to point out reasons for seeking information [40] and may under certain conditions remain anonymous [41], whereas the authorities should explain on what grounds they refuse it [42]. According to the Convention, even where there are reasons for refusing the requested access, it should nonetheless be granted in the cases where the public interest in disclosure is deemed to prevail [43]. That being said, the Convention envisages a very wide list of derogations in which the requested access to official documents may be refused [44]. So far only a few states have become parties to the convention with fourteen states that have signed it [45] and nine that have ratified it [46].

The institutional contribution of international courts and other human rights bodies, including the UNHRC, the European Court of Human Rights (ECtHR), the Inter-American Court of Human Rights (IACHR) and the European Committee on Social Rights [47] should also be noted, as they 'have interpreted existing human rights treaties as protecting a right to information in a range of contexts' [48]. It is noteworthy that the IACHR was the first to decisively endorse the concept of a RTI [49] whereas the ECtHR has rejected it in certain decisions [50] and only recognized it relatively late [51]. As for the UNHRC, it clearly acknowledged the existence of a RTI in its 2011 General Comment 34 on Article 19 of the ICCPR [52].

In 2006, the IACHR delivered its landmark decision in Claude Reyes $v$ Chile [53] which concerned a request for access 'to information relating to a deforestation project' [54]. The court found that a public authority had violated the RTI of the applicant in failing to disclose all of the requested information as well as by not providing a written refusal [55].

As for the ECtHR, its path to recognition of a RTI 'as part of the right to freedom of expression has been long and tortuous' [56]. In its milestone Társaság $A$ Szabadságjogokért $v$. Hungary decision [57], the ECtHR for the first time deemed a refusal by an authority to grant access to information to constitute a breach of the obligation enshrined in Art. 10 of the ECHR. The applicant was an NGO and the ECtHR held that, since its request to receive access was done with the aim of providing arguments for a public discussion of the issue, the refusal of access violated Article 10 [58] and was not 'necessary in a democratic society' [59].

Other bodies such as the United Nations Commission on Human Rights (UNCHR), UNESCO and the UN Special Rapporteur on Freedom of expression have also contributed greatly to the recognition of the RTI. The role played by the UN Special Rapporteur on Freedom of expression, whose mandate was established in 1993 by the UNCHR, has been particularly important. The Special Rapporteur's tasks include the obligations to gather relevant information on interferences with the freedom of opinion and freedom of expression and to propose measures on how to promote these freedoms. UNESCO's main focus is on the freedom of expression. By its initiatives in media and information literacy and in journalism education, UNESCO aims to foster free, independent and pluralistic media. Lastly, a further considerable factor in the gradual development of both national legal systems and international law towards a recognition of a RTI are the NGO's promoting this right. An example of such an NGO is ARTICLE 19 - an organization that 'works for a world where all people everywhere can freely express themselves' [60]. Its main focus are the two interlocking freedoms: "to Speak" and "to Know" [61]. ARTICLE 19 defines the latter freedom as 'the right to demand and receive information by power-holders for transparency, good governance and sustainable development [62]. The NGO enhances international instruments that protect the RTI around the world and produces annual reports on the global state of freedom of expression [63]. The nine 'Principles on Freedom of Information Legislation' drafted by it resonate in legal 
instruments such as the Convention on the Access to Official Documents. The principles provide for 'maximum disclosure' [64], an obligation of public bodies 'to publish key information' [65], for the protection of individuals "who release information on wrongdoing whistleblowers' [66] etc.

\section{Relation of the right to information with participative democracy, accountability and transparency}

It is widely recognized the RTI is crucial to the existence of well-functioning democratcis in that it enables a more active public participation in decision-making. The right to access to environmental information in the Aarhus Convention is granted with the explicit purpose of enabling the public affected to participate in environmental decision-making and of thus attaining a safe environment [67]. The Preamble of the Convention on the Access to official documents also emphasizes that a right to access to official documents enables 'the public to form an opinion' [68] and enhances the public authorities' 'integrity, efficiency, effectiveness and accountability ... so helping affirm their legitimacy' [69].

The importance of the RTI in that regard cannot be overstated. This function of the RTI is closely related to the idea that 'governments hold information not for themselves but on behalf of the wider public' [70] and that 'the essence of representative democracy is informed consent' [71] by 'an informed electorate' [72].

Furthermore, the RTI 'has been widely linked to the achievement of both transparency and accountability' of governments [73]. Transparency of public authorities is considered a quality typical of 'genuinely democratic and pluralist' societies [74]. ARTICLE 19 deems RTI 'an important tool for holding governments to account, as it requires them to be more transparent in their activities, for example in the way they spend public finances. This not only helps fight corruption, but it helps build stable and resilient democracies, where the powerful are genuinely accountable' [75].

Lastly, the UNHRC greatly emphasises the essential role of 'a free, uncensored and unhindered press or other media' [76] in enabling the access to information [78] and an informed formation of public opinion and decision-making. The Committee also underlines the need to effectively protect the media as well as whistleblowers 'against attacks aimed at silencing' them [79]. The UNHRC acknowledges the need for states to ensure the independence of the new kinds of media [80] that have emerged during the last decades due to the recent 'developments in information and communication technologies, such as internet and mobile based electronic information dissemination systems' [81].

\section{Controversial aspects of the right to information}

Despite the importance of RTI, it is practically often questioned since its impact on considerations such as national security or the right to private life are controversial. A RTI that is too wide in scope might negatively affect national security and other legitimate interests. As regards the relation of the RTI to the right of private life, ARTICLE 19 has noted that 'One person's expression may impinge on someone else's privacy and vice versa. This tension is exacerbated by digital technologies, as personal information can be collected and made available across borders on an unprecedented scale and at minimal cost for both companies and states in the digital era' [82].

The relation between the RTI and the freedom of expression, on the one hand, and national security and counterterrorism measures, on the other, is particularly complicated. ARTICLE 19 has stressed in that regard that 'counterterrorism measures and emergency powers have increasingly resulted in or been used to restrict fundamental freedoms, including the rights to assembly, association and expression.' [83]. In view of these conflicting public interests, some limitations of the RTI are necessary 
and unavoidable in order to ensure the right balance. All international legal instruments providing for a RTI regulate derogations from it where the RTI may be overridden by other public interests. Examples of such derogations include art. 19, para. 3 of the ICCPR, art. 4 , para. 3 and 4 of the Aarhus Convention, art. 3 of the Convention on Access to Official Documents and art. 10, para 2 of the ECHR. Among the reasons for derogations listed there are considerations of public order, public health or morals [84], national security, defence and international relations [85], territorial integrity [86], public safety [87], investigation and prosecution of criminal activities [88], privacy and other legitimate private interests [89] etc.

However, the limitations to the RTI should not be too broad - otherwise there is a risk they would be invoked all the time and applied arbitrarily by courts. In that case the RTI would practically be devote of any meaning. It has been consistently underlined by the human rights enforcement bodies and NGO's alike that the limitations to the RTI should always be necessary and proportionate [90] and interfere with the enjoyment of the right to information as little as possible.

In relation to the exceptions contained in art. 19, para. 3 of the ICCPR, the UNHRC has noted that any restrictions to the freedom of expression must be 'provided by law' and must conform to 'strict tests of necessity and proportionality' [91]. In addition, the UNHRC emphasised that any 'restrictions must be constructed with care' [92]. Regarding the requirement of necessity, the UNHRC explained that the test of necessity is always violated where the same level of protection could be achieved through less restrictive measures [93]. As for the proportionality of a certain limitation, account must be taken 'of the form of expression at issue as well as the means of its dissemination' [94].

Helpful as this guidance may be, it is in no way binding when it comes to the interpretation of other international human rights instruments or national laws providing for a RTI. Therefore, it is essential for national and international legislators to very consistently determine and apply the limitations of the RTI in order to ensure its effective enjoyment. In that regard, a very important role may be played by the jurisprudence of international courts.

\section{Conclusions}

The last few decades have seen a tremendous development of national and international law towards a recognition of a RTI, the adoption of a legal framework protecting it and the fuller understanding of its importance for the better functioning of democratic societies. Nevertheless, so as to guarantee the full enjoyment of this right, PIL will need to provide guidance on its exact content as well as on its limitations and its interrelation to other vital considerations such a privacy and security.

\section{References}

[1] Mendel, Toby, Right to Information: Recent Spread of RTI Legislation (World Bank, Washington, DC, 2014) Right to information working paper series, $<$ https://openknowledge.worldbank.org/handle/10986/22528> (visited 12 March 2018), p. 2

[2] Toby Mendel, Right to Information: Recent Spread of RTI Legislation (World Bank, Washington, DC, 2014) Right to information working paper series, $<$ https://openknowledge.worldbank.org/handle/10986/22528> (visited 12 March 2018), p. $2-3$

[3] Maeve McDonagh, 'The Right to Information in International Human Rights Law' (2013) 13:1 Human Rights Law Review, $<$ https://papers.ssrn.com/sol3/papers.cfm?abstract id=2446424>

(visited 12 March 2018) 25-55 p. 25. 
[4] Toby Mendel, Right to Information: Recent Spread of RTI Legislation (World Bank, Washington, DC, 2014) Right to information working paper series, $<$ https://openknowledge.worldbank.org/handle/10986/22528> (visited 12 March 2018), p. 1

[5] Toby Mendel, Right to Information: Recent Spread of RTI Legislation (World Bank, Washington, DC, 2014) Right to information working paper series, $<$ https://openknowledge.worldbank.org/handle/10986/22528> (visited 12 March 2018), p. 1

[6] Toby Mendel, Right to Information: Recent Spread of RTI Legislation (World Bank, Washington, DC, 2014) Right to information working paper series, $<$ https://openknowledge.worldbank.org/handle/10986/22528> (visited 12 March 2018), p. 3

[7] Maeve McDonagh, 'The Right to Information in International Human Rights Law' (2013) 13:1 Human Rights Law Review, $<$ https://papers.ssrn.com/sol3/papers.cfm?abstract $\mathrm{id}=2446424>$ (visited 12 March 2018) 25-55 p. 28

[8] Maeve McDonagh, 'The Right to Information in International Human Rights Law' (2013) 13:1 Human Rights Law Review, $<$ https://papers.ssrn.com/sol3/papers.cfm?abstract_id=2446424> (visited 12 March 2018) 25-55 p. 29

[9] Maeve McDonagh, 'The Right to Information in International Human Rights Law' (2013) 13:1 Human Rights Law Review,

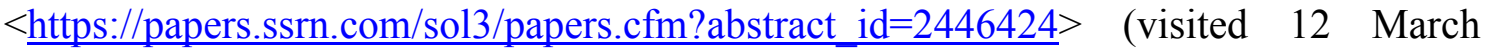
2018) 25-55 p. 29

[10] Article 19, Universal Declaration of Human Rights, G.A. Res. 217A (III), 10 December 1948, U. N. Doc. A/810 at 71 (1948)

[11] Article 19, International Covenant on Civil and Political Rights, 16 December 1966, in force 23 March 1976, 999 UNTS 171

[12] Article 10, European Convention on Human Rights and Fundamental Freedoms, 4 November 1950, in force 3 September 1953, ETS 5

[13] Maeve McDonagh, 'The Right to Information in International Human Rights Law' (2013) 13:1 Human Rights Law Review, $<$ https://papers.ssrn.com/sol3/papers.cfm?abstract_id=2446424> (visited 12 March 2018) 25-55 p. 53-55

[14] The United Nations Special Rapporteur on the promotion and protection of the right to freedom of opinion and expression

[15] Joint Declaration by the UN Special Rapporteur on Freedom of Opinion and Expression, the OSCE Representative on Freedom of the Media and the OAS Special Rapporteur on Freedom of Expression, 6 December 2004 as quoted by Maeve McDonagh, 'The Right to Information in International Human Rights Law' (2013) 13:1 Human Rights Law Review, <https://papers.ssrn.com/sol3/papers.cfm?abstract_id=2446424> (visited 12 March 2018) 25-55 p. 30 fn. 23

[16] Human Rights Committee, General Comment No 34: Freedoms of opinion and expression (art. 19), 12 September 2011, CCPR/C/GC/34; 19 IHRR 303 (2012)

[17] Maeve McDonagh, 'The Right to Information in International Human Rights Law' (2013) 13:1 Human Rights Law Review, $<$ https://papers.ssrn.com/sol3/papers.cfm?abstract id=2446424> (visited 12 March 2018) 25-55 p. 30

[18] Maeve McDonagh, 'The Right to Information in International Human Rights Law' (2013) 13:1 Human Rights Law Review, $<$ https://papers.ssrn.com/sol3/papers.cfm?abstract_id=2446424> (visited 12 March 2018) 25-55 p. 28

[19] Supra note 10 
[20] Supra note 11

[21] Council of Europe Convention on Access to Official Documents 2009, 18 June 2009, ETS 205. The Convention will enter into force when ratified by ten states; as of 26 March 2018, it has been signed by fourteen states, nine of which have ratified it.

[22] The United Nations Economic Commission for Europe Convention on Access to Information, Public Participation in Decision-Making and Access to Justice in Environmental Matters, 25 June 1998, in force 30 October 2001, 161 UNTS 447; 38 ILM 517 (1999)

[23] M. Bossuyt, Guide to the "Travaux Préparatoires" of the International Covenant on Civil and Political Rights (Dordrecht: Martinus Nijhoff Publishers, 1987), pp. 373-402 as quoted by Toby Mendel, Right to Information: Recent Spread of RTI Legislation (World Bank, Washington, DC, 2014) Right to information working paper series, $<$ https://openknowledge.worldbank.org/handle/10986/22528> (visited 12 March 2018), p. 4, fn. 4. In fn. 4 Mendel stated that 'The travaux préparatoires for Article 19 of the ICCPR, meticulously recorded by Marc Bossuyt, do not even hint at this idea'.

[24] Toby Mendel, Right to Information: Recent Spread of RTI Legislation (World Bank, Washington, DC, 2014) Right to information working paper series, $<$ https://openknowledge.worldbank.org/handle/10986/22528> (visited 12 March 2018), p. 4

[25] Supra note 10

[26] Report of the UN Special Rapporteur on the protection and promotion of the right to freedom of opinion and expression, E/CN.4/20.05/64, 2005, para. 39 as quoted by Maeve McDonagh, 'The Right to Information in International Human Rights Law' (2013) 13:1 Human Rights Law Review, $<$ https://papers.ssrn.com/sol3/papers.cfm?abstract id=2446424> (visited 12 March 2018) 25-55 p. 30

[27] Toby Mendel, Right to Information: Recent Spread of RTI Legislation (World Bank, Washington, DC, 2014) Right to information working paper series, $<$ https://openknowledge.worldbank.org/handle/10986/22528> (visited 12 March 2018), p. 4

[28] Supra note 12, Articles 6, 8 and 10

[29] Supra note 22

[30] European Commission, Environment, $<$ http://ec.europa.eu/environment/aarhus/> (visited 25 March 2018)

[31] Supra note 22, Article 6, 7 and 8

[32] Supra note 22, Article 2 item 2

[33] Supra note 22, Article 2 item 5

[34] Supra note 22, Article 9

[35] Supra note 21

[36] Maeve McDonagh, 'The Right to Information in International Human Rights Law' (2013) 13:1 Human Rights Law Review, $<$ https://papers.ssrn.com/sol3/papers.cfm?abstract $\mathrm{id}=2446424>$ (visited 12 March 2018) 25-55 p. 26

[37] Supra note 21, Article 1

[38] Supra note 21, Article 2

[39] <https://www.coe.int/en/web/conventions/full-list/-/conventions/treaty/205> (visited 25 March 2018), Supra note 22, Article 5, 6, 7, 8 and 9

[40] Supra note 21, Article 4 para. 1

[41] Supra note 21, Article 4 para. 2

[42] Supra note 21, Article 5 para. 6 
[43] Supra note 21, Article 3 para. 2

[44] Supra note 21, Article 3 para. 1

[45] <https://www.coe.int/en/web/conventions/full-list//conventions/treaty/205/signatures?p auth $=0$ AGJ4z33 $>$ (visited 25 March 2018) The 14 states that have signed the Convention are Belgium, Bosnia and Herzegovina, Estonia, Georgia, Hungary, Lithuania, Moldova, Montenegro, Norway, Serbia, Slovenia, Sweden, The former Yugoslav Republic of Macedonia and Finland.

[46] <https://www.coe.int/en/web/conventions/full-list//conventions/treaty/205/signatures?p_auth=oAGJ4z33 $>$ (visited 25 March 2018)

[47] Maeve McDonagh, 'The Right to Information in International Human Rights Law' (2013) 13:1 Human Rights Law Review, $<$ https://papers.ssrn.com/sol3/papers.cfm?abstract id=2446424> (visited 12 March 2018) 25-55 p. 28

[48] Maeve McDonagh, 'The Right to Information in International Human Rights Law' (2013) 13:1 Human Rights Law Review, $<$ https://papers.ssrn.com/sol3/papers.cfm?abstract id=2446424 $>$ (visited 12 March 2018) 25-55 p. 26

[49] Claude Reyes and Others v. Chile, Case no. 19/2006, Inter-American Court of Human Rights, Series C 151 (2006), Judgement (19 September 2006), para. 86

[50] Leander v. Sweden, Application No. 9248/81, European Court of Human Rights, 9 EHRR 433, Judgement (26 March 1987)

[51] Társaság A Szabadságjogokért v. Hungary, Application No. 37374/05, European Court of Human Rights, Judgement (14 April 2009)

[52] Supra note 16

[53] Supra note 49

[54] Maeve McDonagh, 'The Right to Information in International Human Rights Law' (2013) 13:1 Human Rights Law Review,

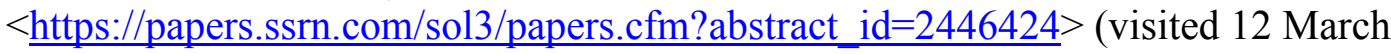
2018) 25-55 p. 33

[55] Supra note 54, para 77

[56] Maeve McDonagh, 'The Right to Information in International Human Rights Law' (2013) 13:1 Human Rights Law Review, $<$ https://papers.ssrn.com/sol3/papers.cfm?abstract id=2446424> (visited 12 March 2018) $25-55$ p. 34

[57] Supra note 49

[58] Supra note 49

[59] Supra note 49

[60] <https://www.article19.org/about-us/> (visited 25 March 2018)

[61] <https://www.article19.org/about-us/> (visited 25 March 2018)

[62] <https://www.article19.org/about-us/> (visited 25 March 2018)

[63] <https://www.article19.org/about-us/> (visited 25 March 2018)

[64] ARTICLE 19, The Public's Right to Know. Principles on Freedom of Information Legislation (ARTICLE 19 London, 1999), International standards series $<$ https://www.article19.org/data/files/pdfs/standards/righttoknow.pdf $>$ (visited 25 Match 2018) Principle 1

[65] ARTICLE 19, The Public's Right to Know. Principles on Freedom of Information Legislation (ARTICLE 19 London, 1999), International standards series $<$ https://www.article19.org/data/files/pdfs/standards/righttoknow.pdf $>$ (visited 25 Match 2018) Principle 2 
[66] ARTICLE 19, The Public's Right to Know. Principles on Freedom of Information Legislation (ARTICLE 19 London, 1999), International standards series $<$ https://www.article19.org/data/files/pdfs/standards/righttoknow.pdf $>$ (visited 25 Match 2018) Principle 9

[67] Supra note 22, para. 1 and Preamble, Recital 9

[68] Supra note 21, Preamble

[69] Supra note 21, Preamb

[70] Toby Mendel, Right to Information: Recent Spread of RTI Legislation (World Bank, Washington, DC, 2014) Right to information working paper series, $<$ https://openknowledge.worldbank.org/handle/10986/22528> (visited 12 March 2018), p. 1

[71] Florini, 'Introduction: The Battle Over Transparency', in Florini (ed.), The Right to Know: Transparency for an OpenWorld (NewYork: Columbia University Press, 2007) 3 as quoted by Maeve McDonagh, 'The Right to Information in International Human Rights Law' (2013) 13:1 Human Rights Law Review, $<$ https://papers.ssrn.com/sol3/papers.cfm?abstract id=2446424> (visited 12 March 2018) 25-55 p. 38 fn. 69

[72] Maeve McDonagh, 'The Right to Information in International Human Rights Law' (2013) 13:1 Human Rights Law Review,

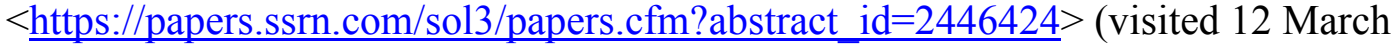
2018) 25-55 p. 38

[73] Supra note 17, para. 20

[74] Maeve McDonagh, 'The Right to Information in International Human Rights Law' (2013) 13:1 Human Rights Law Review,

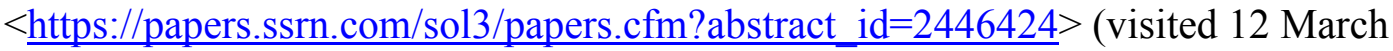
2018) 25-55 p. 53

[75] <https:/www.coe.int/en/web/conventions/full-list/-/conventions/treaty/205> (visited 25 March 2018)

[76] <https://www.article19.org/issue/access-to-information/> (visited 25 March 2018)

[77] Supra note 16, para. 13

[78] Supra note 16, para. 14

[79] Supra note 16, para. 23

[80] Supra note 16, para. 15

[81] Supra note 16, para. 15

[82] < https://www.article19.org/issue/privacy-and-surveillance/ $>$ (visited 25 March 2018)

[83] $<$ https://www.article19.org/resources/counterterrorism-emergency-powers-protectioncivic-space/ $>$ (visited 25 March 2018)

[84] ICCPR art. 19, para.3; ECHR Art. 10, para. 2

[85] Convention on Access to Official Documents Art. 3, para. 1, letter a; Aarhus Convention Art. 4 para. 4 letter b

[86] ECHR Art. 10, para. 2

[87] Convention on Access to Official Documents Art. 3, para. 1, letter b

[88] Convention on Access to Official Documents Art. 3, para. 1, letter c

[89] Convention on Access to Official Documents Art. 3, para. 1, letter f

[90] Supra note 16, para. 22

[91] Supra note 16, para. 22

[92] Supra note 16, para. 28

[93] Supra note 16, para. 33

[94] Supra note 16, para. 34. 